\title{
Protective effects of Annona muricata ethanolic leaf extract against Dimethylnitrosamine (DMN)-Induced Hepatotoxicity.
}

\author{
Usunobun Usunomena \\ Benson Idahosa University, Faculty of Basic and Applied sciences, Department of Biochemistry, P.M.B 1100, \\ Benin City,Edo state, Nigeria, usunsquare@yahoo.com,+2348034174871.
}

\begin{abstract}
The present study was conducted to evaluate the protective role of ethanolic leaf extract of Annona muricata on dimethylnitrosamine (DMN)-induced hepatotoxicity in rat model. DMN administered rats (single dose orally, $12 \mathrm{mg} / \mathrm{kg}$; on day 8) were pretreated with ethanolic leaf extract of Annona muricata $(400 \mathrm{mg} / \mathrm{kg}$ body weight) for 7 days and sacrificed 48hrs after DMN intoxication. Results showed that DMN caused a marked rise in serum alanine aminotransferase (ALT), total cholesterol (TC), as well as marked decrease in serum total protein (TP), globulin, albumin $(A L B), P C V, W B C, R B C$, Hemoglobin and platelet compared to controls. However pretreatment with Annona muricata ethanolic leaf extract produced a significant decrease in the ALT and total cholesterol level and an increase in total protein, globulin, albumin and hematological parameters compared to DMN alone group. Taken these data together, it can be concluded that natural plant components such as Annona muricata leaves could protect the liver against dimethylnitrosamine (DMN)induced liver toxicity.
\end{abstract}

Keywords: Annona muricata, Dimethylnitrosamine, Extract, Hepatotoxicity, Rats,

\section{Introduction}

Liver diseases remain one of the serious health problems. Dimethylnitrosamine (DMN) is a potent hepatotoxin, carcinogen and mutagen [1] which exerts carcinogenic effects, cause fibrosis and induces hepatic necrosis in experimental animals through metabolic activation by CYP2E1 $[1,2,3]$ in experimental animals. In a food survey conducted in Germany, DMN was detected in $31.5 \%$ of analyzed samples with the major dietary sources being cooked meat products, cooked fish and Spices [4]. Analysis of 280 samples of tinned food revealed that $46.1 \%$ contained DMN and/or N-nitrosopiperidine [4]. DMN have also been found in rubber products including gloves, balloons, toys, baby bottle teats, soothers and condoms [5].

Annona muricata L., a genus of Annonaceae, and commonly known in English speaking countries as 'soursop' is an upright, low-branching tree reaching 8 to 10meters [6-8]. The bark, leaves and roots are considered sedative, antispasmodic, hypoglycemic, hypotensive, smooth muscle relaxant and nervine and a tea is made for various disorders for those purposes [9-11]. Traditionally, the leaves are used for headaches, insomnia, cystitis, liver problems, diabetes, hypertension and as an anti-inflammatory, antispasmodic and antidysenteric [12-14]. The plant has been reported to possess acetogenins as major phytoconstitutents [15] which are responsible for number of activities such as antitumor, immunomodulator, antispasmodic, antimalarial, pesticidal, antiparasitic, antibacterial, antifungal and antihelmintic activity [16]. The annonaceous acetogenins are selectively toxic to cancer cells, including multi-drug-resistant cancer cell lines [17-21]. Annonaceous acetogenins induce cytotoxicity by inhibiting the mitochondrial complex I, which is involved in ATP synthesis [18]. The pharmaceutical imbalance in remedies that could protect the liver and have antioxidant properties and drugs that induces hepatotoxicity has prompted the research into plants used in folk medicine to treat liver diseases and boost liver functions, and Annona muricata is one of such plant that has scientifically been proven to contain phytochemical principles from which its antitumor and antimicrobial properties are derived. Therefore, in this study, the ability of activity directed extracts of Annona muricata leaf to protect the liver against $\mathrm{DMN}$-induced hepatocellular damage in rats in vivo is investigated.

\section{1 Preparation and extraction of the plant leaves}

\section{Materials And Method}

The Annona muricata leaf samples were gotten from Benin City, Edo state, Nigeria and authenticated by a botanist at the Department of Basic sciences, Benson Idahosa University. Fresh matured leaves of Annona muricata were separated from stalk, washed and air-dried at room temperature $\left(24^{\circ} \mathrm{C}\right)$ and then pulverized, crushed into fine powder using a manual blender and weighed. Ethanolic (Absolute) extracts of the plant were prepared by soaking $800 \mathrm{~g}$ of the dry powered plant material in 2litres of absolute ethanol and then kept at room temperature for 48hours (for thorough extraction). At the end of the 48hours, the extracts were filtered first using a Whatmann filter paper No.42 $(125 \mathrm{~mm})$ and then with cotton wool. The Annona muricata ethanolic leaf extracts were concentrated using a rotary evaporator with water bath set at $60^{\circ} \mathrm{C}$ to one-tenth its original volume 
and then finally with water bath at $37^{\circ} \mathrm{C}$. The dried residue (crude extract) was then stored at $4^{\circ} \mathrm{C}$. Aliquot portion of the crude plant extract residue was weighed and dissolved in distilled water for use on each day of experiment.

\subsection{Apparatus}

During the course of the experiment, the following apparatus were used to achieve the desired results. They includes Rotary evaporator, water bath, measuring cylinder, beakers, filter paper, cotton wool, funnel, weighing balance, spectrophotometer, cuvette, centrifuge, test tubes, stopwatch, syringes, spatula.

\subsection{Chemicals}

Absolute ethanol, Dimethylnitrosamine (DMN), Sodium hydroxide Solution. DMN used in this work was synthesized in a fume chamber at the Department of Biochemistry, University of Ibadan, Oyo state, Nigeria, according to the method of Vogel [22].

\subsection{Experimental animals}

Twenty six male albino wistar rats that weighed between $155-205 \mathrm{~g}$ gotten from Edo state, Nigeria were used for the experiment. The animals approved by Benson Idahosa University Ethical Committee in accordance with "Principles of Laboratory Animal Care" were kept in Biochemistry Departments' animal house. The condition of the animal house was of standard and appropriate cleaning was ensured.

\subsection{Administration of plant extract and toxicant}

A total of twenty six male wistar rats were specifically assigned into one of the following groups:

\begin{tabular}{|l|l|l|l|}
\hline Groups & Number of rats & Treatment & Body weight \\
\hline 1 & 5 & Control (normal saline) & $155 \mathrm{~g}-160 \mathrm{~g}$ \\
\hline 2 & 8 & DMN alone $(12 \mathrm{mg} / \mathrm{kg})$ & $190 \mathrm{~g}-205 \mathrm{~g}$ \\
\hline 3 & 6 & Annona muricata alone $(400 \mathrm{mg} / \mathrm{kg})$ & $160 \mathrm{~g}-170 \mathrm{~g}$ \\
\hline 4 & 7 & $\begin{array}{l}\text { Annona muricata }(400 \mathrm{mg} / \mathrm{kg})+\text { DMN } \\
(12 \mathrm{mg} / \mathrm{kg})\end{array}$ & $170 \mathrm{~g}-180 \mathrm{~g}$ \\
\hline
\end{tabular}

- Control rats received normal saline.

- Rats in group 3 and 4 were administered $400 \mathrm{mg} / \mathrm{kg}$ of Annona muricata for 7 days

- Rats in group 2 and 4 received a single oral dose of $12 \mathrm{mg} / \mathrm{kg}$ DMN on day 8 . DMN was prepared using physiological saline.

\subsection{Blood collection}

At day 10 of experiment, rats from each group were weighed and sacrificed by cervical dislocation. Blood samples were obtained through heart puncture for hematological and liver function analysis. Blood for hematology was collected using EDTA bottles. Blood samples for liver function analysis were taken into centrifuge tube with rubber caps, labeled and centrifuged at $3000 \mathrm{rpm}$ for $15 \mathrm{~min}$.

\subsection{Biochemical analysis}

Serum AST was determined by the method of Reitman and Frankel [23]. Serum total protein and albumin were analyzed using the biuret and bromocresol green methods, respectively. In both cases, commercially available test kits, products of Randox laboratories, U.K. were used and with the manufacturers instructions strictly adhered to. The globulin concentration was calculated by subtracting the albumin concentration from the total protein concentration. Serum total cholesterol was measured using commercial enzyme assay kits (Randox laboraties, U.K).

Hematological parameters like haemoglobin $(\mathrm{Hb})$, Packed cell volume (PCV), red blood cells (RBC), white blood cells (WBC) and platelet were monitored using Hemavet 850 (CDC technologies, oxford, CT) at the University of Benin teaching hospital.

\subsection{Statistical Analysis}

Results are reported as mean \pm standard deviation (SD). Statistical analysis was performed using oneway analysis of variance (ANOVA). The value of $p<0.05$ was considered as statistically significant.

\section{Results}

Administration of single dose of $12 \mathrm{mg} / \mathrm{kg}$ body weight of DMN to wistar rats produced significant changes in the biochemical parameters when compared to the control group. ALT and total cholesterol were significantly elevated $(\mathrm{P}<0.05)$, while the serum total protein, globulin and albumin levels were reduced in the DMN-treated rats as compared to the control group (Tables 1). However pretreatment of the rats with $400 \mathrm{mg} / \mathrm{kg}$ 
Annona muricata ethanolic leaf extract produced a significant reduction in the levels of ALT and total cholesterol as well as significant increase in the levels of total protein, globulin and albumin compared to values in the DMN alone treated group.

DMN treatment also significantly decreased WBCs, platelet, haemoglobin, RBCs, and PCV in DMN alone treated group compared to other groups (Table 2). However, Annona muricata pretreatment significantly mitigated the induced changes in hematological parameters.

Table 1: Effect of Annona muricata ethanolic leaf extract on serum AST, TC, TP and ALB in DMN-induce toxicity.

\begin{tabular}{|l|l|l|l|l|l|}
\hline GROUPS & $\begin{array}{l}\text { ALT } \\
(\mathrm{U} / \mathrm{L})\end{array}$ & $\begin{array}{l}\text { TC } \\
(\mathrm{mg} / \mathrm{dl})\end{array}$ & $\begin{array}{l}\text { TP } \\
(\mathrm{g} / \mathrm{dl})\end{array}$ & $\begin{array}{l}\text { ALB } \\
(\mathrm{g} / \mathrm{dl})\end{array}$ & $\begin{array}{l}\text { Globulin } \\
(\mathrm{g} / \mathrm{dl})\end{array}$ \\
\hline Group 1 (control) & $18.64 \pm 3.67^{\mathrm{a}}$ & $97.31 \pm 8.27^{\mathrm{a}}$ & $8.01 \pm 0.12^{\mathrm{a}}$ & $3.70 \pm 0.18^{\mathrm{a}}$ & $4.31 \pm 0.06^{\mathrm{a}}$ \\
\hline Group 2 (12mg/kg DMN alone) & $69.12 \pm 1.72^{\mathrm{b}}$ & $157.69 \pm 12.10^{\mathrm{b}}$ & $4.74 \pm 0.30^{\mathrm{b}}$ & $2.40 \pm 0.04^{\mathrm{b}}$ & $2.34 \pm 0.01^{\mathrm{b}}$ \\
\hline $\begin{array}{l}\text { Group 3 }(400 \mathrm{mg} / \mathrm{kg} \text { Annona } \\
\text { muricata } \text { alone) }\end{array}$ & $18.550 \pm 2.48^{\mathrm{a}}$ & $105.26 \pm 7.89^{\mathrm{a}}$ & $7.92 \pm 0.37^{\mathrm{a}}$ & $3.60 \pm 0.13^{\mathrm{a}}$ & $4.32 \pm 0.24^{\mathrm{a}}$ \\
\hline $\begin{array}{l}\text { Group 4 }(400 \mathrm{mg} / \mathrm{kg} \text { Annona } \\
\text { muricata }+12 \mathrm{mg} / \mathrm{kg} \text { DMN }\end{array}$ & $38.28 \pm 2.36^{\mathrm{c}}$ & $117.87 \pm 5.88^{\mathrm{a}}$ & $6.11 \pm 0.21^{\mathrm{c}}$ & $2.84 \pm 0.13^{\mathrm{c}}$ & $3.27 \pm 0.08^{\mathrm{c}}$ \\
\hline
\end{tabular}

Values are expressed as mean $\pm \mathrm{SD}, \mathrm{n}=5$, DMN=Dimethylnitrosamine; ALT=Alanine aminotransferase; $\mathrm{TC}=$ Total cholesterol; $\mathrm{TP}=$ Total protein; $\mathrm{ALB}=\mathrm{Albumin}$.

Data are statistically significant at $\mathrm{P}<0.05$ compared to normal control group. Values with the same superscript in each column $(a, b, c, d)$ are not significantly different $(p<0.05)$.

Table 2: Effect of Annona muricata ethanolic leaf extract on hematological parameters in DMN-induced toxicity.

\begin{tabular}{|l|l|l|l|l|}
\hline $\begin{array}{l}\text { Hematological } \\
\text { Parameters }\end{array}$ & Control Group & $\begin{array}{l}\text { Group 2 } \\
(12 \mathrm{mg} / \mathrm{kg} \mathrm{DMN})\end{array}$ & $\begin{array}{l}\text { Group 3 } \\
(400 \mathrm{mg} / \mathrm{kg} \text { Annona } \\
\text { muricata Only) }\end{array}$ & $\begin{array}{l}\text { Group 4 (400mg/kg } \\
\text { Annona muricata }+ \\
12 \mathrm{mg} / \mathrm{kg} \mathrm{DMN})\end{array}$ \\
\hline $\mathrm{WBC}\left(\times 10^{3} / \mathrm{ll}\right)$ & $12.36 \pm 0.10^{\mathrm{a}}$ & $2.75 \pm 0.45^{\mathrm{b}}$ & $7.55 \pm 0.53^{\mathrm{d}}$ & $8.06 \pm 3.52^{\mathrm{d}}$ \\
\hline RBC $\left(\times 10^{6} / \mathrm{ll}\right)$ & $8.97 \pm 1.57^{\mathrm{a}}$ & $7.73 \pm 0.72^{\mathrm{b}}$ & $9.96 \pm 0.56^{\mathrm{a}}$ & $9.50 \pm 0.56^{\mathrm{a}}$ \\
\hline Hemoglobin $(\mathrm{g} / \mathrm{dl})$ & $13.90 \pm 0.51^{\mathrm{a}}$ & $11.20 \pm 0.50^{\mathrm{b}}$ & $14.45 \pm 0.73^{\mathrm{a}}$ & $14.20 \pm 0.44^{\mathrm{a}}$ \\
\hline Platelet $\left(\times 10^{3} / \mathrm{yl}\right)$ & $320.10 \pm 23.10^{\mathrm{a}}$ & $83.00 \pm 10.66^{\mathrm{b}}$ & $435.00 \pm 28.08^{\mathrm{c}}$ & $179.69 \pm 30.50^{\mathrm{d}}$ \\
\hline PCV $(\%)$ & $42.50 \pm 4.50^{\mathrm{a}}$ & $32.75 \pm 1.06^{\mathrm{b}}$ & $42.45 \pm 1.05^{\mathrm{a}}$ & $42.40 \pm 0.55^{\mathrm{a}}$ \\
\hline
\end{tabular}

Values are given as mean \pm standard deviation, $\mathrm{n}=5, \mathrm{DMN}=$ Dimethylnitrosamine, $\mathrm{WBC}=$ White blood cell, $\mathrm{RBC}=$ Red blood cell, $\mathrm{PCV}=$ Packed cell volume

Data are statistically significant at $\mathrm{P}<0.05$ compared to normal control group. Values with the same superscript in each row (a, b, c, d) are not significantly different $(\mathrm{p}<0.05)$.

\section{Discussion}

Liver disease and toxicity is common, especially with many drug treatments. Serum activities of AST and ALT are the most commonly used biochemical markers of liver injuries. Level of ALT, a marker enzyme of liver injury increased significantly in the DMN alone group after DMN administration $(\mathrm{p}<0.05)$ compared to normal control and extract pretreated groups (Table 4.1). The increase in activities of ALT, a liver marker enzyme in the serum of DMN alone induced rats indicates damage to hepatic cells. The abnormal high level of serum ALT in this study is a consequence of DMN-induced liver dysfunction. The increase in serum level of AST and ALT have been attributed to the damaged structural integrity of the liver. This is because they are cytoplasmic in their location and are released into circulation after cellular damage [24]. The result of this study however demonstrated that pretreatment with ethanolic leaf extract of Annona muricata significantly caused a decrease in serum ALT in comparison to DMN alone group. Thus the extract protected the hepatocytes from DMN-induced injuries. The stabilization of transaminases denotes the renewal of the normal hepatic activity. The efficacy of any hepatoprotective drug is dependent on its capacity of either reducing the harmful effect or restoring the normal hepatic physiology that has been distributed by a hepatotoxin. Annona muricata ethanolic leaf extract decreased $(p<0.05)$ DMN-induced elevated ALT levels in tested groups, indicating the protection of structural integrity of hepatocytic cell membrane or regeneration of damaged liver cells [25].

Lipids are the most important cellular entities which are not only the constituents of cell membrane but also involved in many cellular functions, metabolic processes and are vital for energy production. Liver is the organ involved in the synthesis of lipoproteins and metabolism of cholesterol. Honma and Sudha, [26] reported that the changes in plasma lipids level could be sensitive and serve as a simple marker for assessing liver disorders. The results of the present study have established that, the DMN treatment could have affected the lipid metabolism of liver cholesterol levels. This is evidenced from the present observations that, DMN caused a significant $(\mathrm{p}<0.05)$ increase in the levels of total cholesterol (Table 1). It can be assumed that hypercholesterolemia in DMN intoxicated rats was resulted from damage of hepatic parenchymal cells that lead 
to disturbance of lipid metabolism in liver [27]. The elevated level of serum cholesterol in DMN alone group may be attributed to increase in the concentration of acetyl CoA arising probably from enhanced $\beta$-oxidation of fatty acid [28]. However, rats pretreated with Annona muricata ethanolic leaf extract showed a significant $(\mathrm{p}<$ $0.05)$ decline in cholesterol values compared to DMN-intoxicated alone rats. The mechanism of lipid lowering effects of Annona muricata extract might be attributed to an inhibitory activity on microsomal acyl coenzyme A: cholesterol acyltransferease in vitro. This enzyme is responsible for acylation of cholesterol to cholesterol esters in liver [29].

Proteins are important organic constituents of the animal cells playing a vital role in the process of interactions between intra and extra cellular media. Being a part of cell membrane and as an enzyme, protein participates in the intricately balanced subcellular fractions. The depletion in the protein levels might be because of their metabolism to liberate energy during toxicity. Protein plays a major role in the synthesis of microsomal detoxifying enzymes and helps to detoxify the toxicants, which enter into the animal body [30]. The liver not only synthesizes the proteins for its needs but produces numerous export proteins. Among these proteins, serum albumin is the most important. Albumin is quantitatively the most important soluble plasma protein. It plays various important biological roles including maintenance of plasma oncotic pressure [31]. Due to its ability to bind reversibly, it act as a transporter protein for many endogenous and exogenous compounds including various hormones, non-steroidal anti-inflammatory drugs; maintenance of intravascular volume and capillary permeability, removal of potentially toxic compounds and dissociation of free radicals, along with neutrophil activation and adhesion [32-34]. Albumin is produced entirely in the liver and is of great importance in regulating the flow of water between the plasma and tissue fluid by its effect on colloid osmotic pressure. In this study, DMN induced liver damage in rats which is indicated by the decrease in levels of serum albumin, total protein and globulin (Table 1). However, pretreatment of rats with Annona muricata ethanolic leaf extract effectively protected the rats against DMN-induced hepatotoxicity as evidenced by the increase in contents of total protein, albumin and globulin. The decrease in serum total protein observed in DMN alone treated group (Table 4.1) may be associated with the decrease in the number of hepatocytes which in turn may have led to the decreased hepatic capacity to synthesize protein [35] but the restoration of the level of serum total protein and albumin upon pretreatment of Annona muricata ethanolic leaf extract is a reflection of the hepatoprotective nature of this plant. The decrease in serum total protein in DMN alone group agrees with George [36], that decrease in serum protein in hepatotoxicity states simply indicates the presence of para proteins or decreased antibody production. A drop in serum albumin level is usually the result of deceased protein synthesis by the liver or increased protein loss through the gut or the kidney. Other possible cause of decrease in albumin may include malabsorption and increased protein need secondary to infection.

The observed protective effect of the plant extract against DMN may be attributed to the presence of acetogenins, flavonoids, tannins, ascorbic acid and phenols among the plant constituents [37-40]. Flavonoids are known to be antioxidants, free radical scavengers and antilipoperoxidant leading to hepatoprotection. The mechanism by which Annona muricata exerts protection against DMN-induced alterations in the liver may be due to the antioxidative and acetogeninic effect of the plants extract. In this study, we observed that pretreatment of $400 \mathrm{mg} / \mathrm{kg}$ b.w of ethanolic leaf extract of Annona muricata to rats decreased the DMN-induced elevated ALT and total cholesterol as well as increased DMN-induced depressed total protein, globulin and albumin level in the treated groups. This suggests the maintenance of structural integrity of the hepatocytic cell membrane or regeneration of damage liver cells by the extract.

Hematological parameters generally provide information on inflammation, necrosis, various infections of visceral organs and the presence of stress factors [41-43]. White blood cells (WBCs), or leukocytes, play the main role in immune responses. These cells carry out the many tasks required to protect the body against disease-causing microbes and abnormal cells. Some types of leukocytes patrol the circulation, seeking foreign invaders and diseased, damaged, or dead cells. These WBCs provide a general—or nonspecific - level of immune protection [44-45]. Serum proteins have many functions, including the transport of other substances, immune defense, blood clotting, and inflammation defense. In the present study, DMN decreased the WBCs, Platelets, Red blood cells (RBCs), packed cell volume (PCV), and Hemoglobin (Hb) in DMN alone treated group compared to control and extract pretreated groups. The significant reductions in the WBCs and possibly lymphocytes in DMN alone group (Table 2) would predispose the animals to reduced immunological responses to infections. Pretreatment with $400 \mathrm{mg} / \mathrm{kg}$ Annona muricata significantly enhanced the WBCs, platelets, PCV, RBCs and Hemoglobin (Table 2). This indicates that Annona muricata improves immunity function and decrease inflammation. Studies has shown that decrease in WBC count could be as a result of bone marrow deficiency or failure due to infection, cancer treating drugs that damage the bone marrow, disease of the liver or spleen. It had been reported that a significant decrease in the WBCs of the blood indicates a decline in the production of the defensive mechanism to combat infections, a situation which would naturally make the animal more susceptible to various physiological stress resulting in diseases, greater mortality and poor growth [46]. The significant reductions in the haemoglobin, PCV and RBCs contents of the blood of DMN alone group 
(Table 2) is an indication that the oxygen carrying capacity of the animals' blood would be reduced [47]. Anemia is defined as a reduction in the haemoglobin concentration of the blood [48]. Reduction in the haemoglobin may be accompanied by a fall in RBC and PCV [48]. The major function of the RBCs is to transport haemoglobin, which in turn carries oxygen from the lungs to the tissues [49]. Very low readings for $\mathrm{RBC}$, heamoglobin and hematocrit can indicate anemia. Lower-than-normal hemoglobin may be due to anemia (various types), bleeding, destruction of RBCs, leukemia etc. Furthermore, when the platelets count is low as observed for the rats in DMN alone group (Table 2), clot retraction is deficient and there is poor constriction of ruptured vessels. The resulting clinical syndrome (thrombocytopenic purpura) is characterized by easy bruisability and multiple subcutaneous hemorrhages [50]. Therefore, the significant reduction in the platelets of the blood of DMN alone group is an indication that they may not be able to cope with blood coagulation as effectively as the rats in the control or in the Annona muricata extract pretreated groups. Lower -than - normal PCV may be sign of anemia, bleeding, destruction of red blood cells, leukemia, malnutrition, nutritional deficiencies of iron, folate, vitamin $\mathrm{B}_{12}$, and vitamin $\mathrm{B}_{6}$, over hydration [51].

Annona muricata is known to have wide therapeutic applications in folk medicine and scientific advancement has provided substantial evidence to support most of its medicinal claims. The present in vivo study has further demonstrated the hepatoprotective potential of this plant. In this study hepatocellular damage induced by dimethylnitrosamine (DMN) intoxication in rat was established based on significant increase in ALT and total cholesterol, significant decrease $(\mathrm{P}<0.05)$ in total protein level, albumin, globulin, $\mathrm{PCV}$, hemoglobin, WBCs, RBCs and platelets in the DMN alone group compared to the normal control group.

In conclusion, the present results demonstrate that Annona muricata leaves play an important role in the protection against dimethylnitrosamine (DMN)-induced hepatotoxicity, by improving the activities of ALT, total cholesterol, total protein, albumin, globulin and hematological parameters. Therefore, Annona muricata may be used to protect against toxic effects of DMN and other chemical agents in liver. In the future, examination of the protective effect of Annona muricata ethanolic leaf extract against DMN in dose dependant manner could be investigated.

\section{Acknowledgements}

The author is grateful to the Biochemistry Department at Benson Idahosa University for providing the laboratory equipments

\section{References}

[1]. George, J., Rao, K.R., Stern, R., and Chandrakasan, G. Dimethylnitrosamine-induced liver injury in rats: the early deposition of collagen. Toxicology 2001;156:129-138.

[2]. Guengerich, F.P., Kim, D.H., and Iwasaki, M. role of human ccytochrome P-450IIEI in the oxidation of many low molecular weight cancer suspects. Chemical Research in Toxicology 1991;4:168-179.

[3]. Kasprzyk-Hordern B, Andrzejewski P, and Nawrocki J. The hazard of N-nitrosodimethylamine (NDMA) formation during water disinfection with strong oxidants. Desalination 2005;176:37-45.

[4]. Domanska, K. and B. Kowalski. Effect of different storage conditions on N-nitrosamine content in Polish edible offals processed meat products. Bull. Ver. Inst. Pulawy, 2002;46: 317-324.

[5]. Proksch, E., Toxicological evaluation of nitrosamines in condoms. Int. J. Hyg. Environ. Health., 2001;204(2): 103-110

[6]. Popenoe W. Manual of Tropical and Subtropical Fruits. Hafner Press, New York, 1920, 8.

[7]. Mowry H., Toy L.R. and Wolfe H.S., Miscellaneous tropical and subtropical Florida fruits. Florida Agricultural Experiment Station, Bulletin 156, 1953.

[8]. Morton J.F., Fruits of Warm Climates. Florida Flair Books, Boynton Beach, Florida, 1987, 75-80.

[9]. Holdsworth D.K., “Traditional Medicinal Plants of Rarotonga, Cook Islands.” Part I. Int. J. Crude Drug Res. 1990; 28(3): $209-218$.

[10]. Gouemo N.P., Yasuda R.P., and Morad M., Audiogenic seizure alters the expression of calcium and potassium channel protein in inferior colliculus neurons of the genetically epilepsy-prone rat (GEPR-3). Abs. Soc. Neurosci. Program, 2003; $212-220$.

[11]. Yuan S.S., Chang H.L., Chen H.W., Annonacin, a mono-tetrahydrofuran acetogenin, arrests cancer cells at the G1 phase and causes cytotoxicity in a bax- and caspase-3- related pathway. Life Sci, 2003;72: 2853-61.

[12]. Di Stasi, L.C.; and Hiruma-Lima, C.A. Plantas Medicinais na Amazônia e na Mata Atlântica, 2nd ed.; Editora UNESP: São Paulo, Brazil, 2002; 87-112.

[13]. Sousa, M.P.; Matos, M.E.O.; Matos, F.J.A.; Machados, M.I.L.; and Craveiro, A.A. Constituintes Químicos Ativos e Propriedades Biológicas de Plantas Medicinais Brasileiras, 2nd ed.; Editora UFC: Fortaleza, Brazil, 2004; 281-283.

[14]. Taylor L., Technical Data Report for Graviola: Annona Muricata. Sage Press, Inc. Herbal Secrets of the Rainforest second ed., 2002.

[15]. Padma P, Khosa RL, and Sahai M, Acetogenin from Genus Annona - A Review. Indian Journal of Natural Products, 1996;12(3):321.

[16]. Padma P, Phytochemical studies and Evaluation of Biological activity of some Medicinal Plants, PhD Thesis, Department of Pharmaceutics, Banaras Hindu University, Varanasi, 1997; 141-195.

[17]. Oberlies N.H., J.L. Jones, T.H. Corbett, S.S. Fotopoulos, and J.L. McLaughlin, Tumor cell growth inhibition by several annonaceous acetogenins in an in vitro disk diffusion assay. Cancer Lett. 1995;96:55-62.

[18]. McLaughlin J.L., Paw paw and cancer: annonaceous acetogenins from discovery to commercial products. J. Nat. Prod. 2008;71:1311- 1321 .

[19]. Tormo J.R., I. Royo, T. Gallardo, M.C. Zafra-Polo, P. Hernandez, D. Cortes, and F. Pelaez, In vitro antitumor structure-activity relationships of threo/trans/threo mono-tetrahydrofuranic acetogenins: correlations with their inhibition of mitochondrial complex I. Oncol. Res. 2003;14:147-154. 
[20]. Chang F.R., and Wu Y.C., Novel cytotoxic annonaceous acetogenins from Annona muricata, J. Nat. Prod. 2001;64:925-931.

[21]. Liaw C.C., F.R. Chang, C.Y. Lin, C.J. Chou, H.F. Chiu, M.J. Wu, and Y.C. Wu, New cytotoxic monotetrahydrofuran annonaceous acetogenins from Annona muricata, J. Nat. Prod. 2002; $65: 470-475$.

[22]. Vogel. A. I. A textbook of practical organic Chemistry including qualitative organic analysis. Longman group limited, London. 1971; Pp 426 .

[23]. Reitmans and Frankel, S. A colorimetric method for the determination of SGOT and SGPT. Am. J. Cln. Path. 1957; 28: 56-58.

[24]. Huang, C.H., Horng, L.Y., Chenc, C.F., and Wu, R.T. Chinese herb Radix Polygoni Multiflori as a therapeutic drug for liver cirrhosis in mice. Journal of Ethnopharmacology. 2007; 114:199-207

[25]. Palanivel M.G., Rajkapoor B., Kumar R.S. Hepatoprotective and antioxidant effect of pisonia aculeata L. Against CCl4- induced hepatic damage in rats. Sci. Pharm. 2008;76:203-215

[26]. Honma, T., and Sudha, M., Indian Health 1997, 34, 519-531.

[27]. Havel R.J. Functional activities of hepatic lipoproteins receptors. Ann. Rev. Physiol. 1986;48:119-134.

[28]. Rang H. P., Dale M. M., and Ritter J.M. Pharmacology. 3rd edn. (Churchill Livingstone, New York 1995.

[29]. Matsuda K. ACAT inhibitors as antiatherosclerotic agents: compounds and mechanisms. Med. Res. Rev. 1994;14:271-305.

[30]. Ramasamy, M., Effects of Sevin on blood free amino acid levels of the fish Sarotherodon mossambicus. Environ. Environ. Ecol. 1987;5:633-637.

[31]. Peter T. Jr. All about Albumin, Biochemistry, Genetics, and Medical Applications, Academic Press, San Diego, 1996.

[32]. Halliwell B. Albumin-an important extracellular antioxidant? Biochem. Pharmacol. 1988; 37:569-571.

[33]. Bourdon E, Loreau N, and Blache D. Glucose and free radicals impair the antioxidant properties of serum albumin. FASEB J.1999; 13:233-244.

[34]. Fasano M, Curry S, Terreno E, Galliano M, Fanali G, and Narciso P, . The extraordinary ligand binding properties of human serum albumin. IUBMB Life. 2005; 57:787-796.

[35]. Shahjahan M., Sabitha K. E., Mallika J., and Shyamala-Devi C. S. Effect of Solanum trilobatum against carbon tetrachloride induced hepatic damage in albino rats. Indian J. Med. Res. 2004;120:194-198.

[36]. George R. K. Biochemistry Laboratory. Philadelphia www.jbc.org. 2009.

[37]. Edeoga H.O., Okwu D.E., and Mbaebie B.O. Phytochemical Constituents of some Nigerian Medicinal Plants. Afr. J. Biotechnol. 2005;4:685-688.

[38]. Falodun A., Osakue J., Uzoekwe A. S. and Sheng-Xiang Q. Phytochemical and anticancer studies in ten medicinal plants used in Nigeria. Bayero Journal of Pure and Applied Sciences, 2011;4(1): 36 - 39.

[39]. Foong C. P. and Hamid R. A. Evaluation of anti-inflammatory activities of ethanolic extract of Annona muricata leaves. Rev. bras. farmacogn. 2012; 22:6.

[40]. Vijayameena C., G. Subhashini, M. Loganayagi and B. Ramesh . Phytochemical screening and assessment of antibacterial activity for the bioactive compounds in Annona muricata. Int. J. Curr. Microbiol. App. Sci. 2013; 2(1): 1-8

[41]. Jurcik R., Suvegova K., Hanusova E., Massanyi P., Ryban L., and Chrenek P. Evaluation of haematological, biochemical and histopathological parameters of transgenic rabbits. J. Vet. Med. A, 2007;54: 527-531.

[42]. Melillo A. Rabbit clinical pathology. J. Exot. Pet Med., 2007;16:135-145.

[43]. Betancourt-Alonso M.A., Orihuela A., Aguirre V., Vázquez R., and Flores-Pérez I. Changes in behavioural and physiological parameters associated with Taenia pisiformis infection in rabbits (Oryctolagus cuniculus) that may improve early detection of sick rabbits. World Rabbit Sci., 2011;19: 21-30.

[44]. Lee, Y. J.; Lee, H. R.; Shim, J. Y.; Moon, B. S.; Lee, J. H.; and Kim, J. K. Relationship between white blood cell count and nonalcoholic fatty liver disease. Digest. Liver Dis. 2010; 42:888-894.

[45]. Bianchini, F.; and Wild, C.P. Effect of route of administration of environmental methylating agents on 7-methylguanine formation in white blood cells and internal organs: implications for molecular epidemiology. Cancer Lett. 1994, 87:131-137.

[46]. Agrawal, N.K. and C.I. Mahajan. Hematological changes due to vitamin C deficiency in Channa punctatus block. J. Nutr., 1980;110: 2172-2182.

[47]. Aduloju, Y.O., Blood composition of broiler chicks fed raw or processed fullfat soybeans supplemented with Saccharomyces cerevisae. B.Sc. Project, Department of Animal Production, University of Ilorin, Nigeria. 2000

[48]. Moss, P.P. Blood banking: Concepts and Applications. W.B. Saunders Co. Philadelphia, 1999;12-34.

[49]. Waugh, A. and A. Grant. Anatomy and Physiology in Health and Illness. 9th ed. Churchill Livingstone, an Imprint of Elsevier Science Limited, 2001; 59-70.

[50]. Roit, M.M. Essential Haematology. 7 edition. Harcourt Press, 2001; 1-19.

[51]. Bunn H.F. Approach to the anemias. In: Goldman L, Schafer AI, eds. Cecil Medicine. 24th ed. Philadelphia, Pa: Saunders Elsevier; Chap. 161. 2011. 